\title{
KESIAPAN KERJA SISWA PROGRAM AKUNTANSI PADA SEKOLAH MENENGAH KEJURUAN
}

\author{
Beny Dwi Saputra ${ }^{1}$ dan Sukirno ${ }^{2}$ \\ ${ }^{1}$ Program Pascasarjana Universitas Negeri Yogyakarta \\ ${ }^{2}$ Fakultas Ekonomi Universitas Negeri Yogyakarta \\ email: beny.dwi2016@student.uny.ac.id
}

\begin{abstract}
Abstrak
Penelitian ini bertujuan untuk mengetahui pengaruh secara individual dan simultan prestasi belajar akuntansi komputer, kompetensi pedagogik guru, lingkungan sekolah, dan praktik kerja industri terhadap kesiapan kerja siswa Program Keahlian Akuntansi SMK di Daerah Istimewa Yogyakarta. Penelitian ini merupakan penelitian asosiatif kausal dengan sasaran siswa kelas XII Program Keahlian Akuntansi SMK Daerah Istimewa Yogyakarta Tahun Pelajaran 2018/2019. Sampel sebanyak 207 siswa dipilih dari lima sekolah mewakili lima wilayah di Yogyakarta dengan teknik purposive sampling. Teknik pengumpulan data menggunakan kuesioner dan dokumentasi. Data dianalisis dengan metode analisis regresi berganda. Hasil penelitian menunjukkan bahwa prestasi belajar akuntansi komputer, kompetensi pedagogik guru, lingkungan sekolah, dan praktik kerja industri berpengaruh secara positif dan signifikan terhadap kesiapan kerja siswa dengan sumbangan efektif sebesar 47,9\%. Banyak faktor yang mempengaruhi kesiapan kerja seorang siswa. Kesiapan kerja dapat dipengaruhi dan dibentuk oleh pengalaman. Faktor lingkungan yang dapat mempengaruhi kesiapan kerja yaitu lingkungan sekolah, kompetensi pedagogik guru yang mengajar dan keberhasilan mereka dalam praktik kerja industri.
\end{abstract}

Kata kunci: kesiapan kerja, prestasi belajar, kompetensi pedagogik, praktik kerja industri

\section{WORK READINESS OF ACCOUNTING PROGRAM STUDENTS AT VOCATIONAL HIGH SCHOOL}

\begin{abstract}
This study was aimed at determining the influence of individual and simultaneous computer accounting learning achievement, teacher pedagogical competence, school environment and industrial work practices on work readiness of the students of vocational accounting expertise program in Yogyakarta. This study was a causal associative research, with the students of class XII in the Accounting Skills Program of Vocational School in Special Region of Yogyakarta in the academic year 2018/2019 as the research subject. The sample of 207 students were selected from five schools representing five regions in Yogyakarta using purposive sampling technique. Questionnaires and documentation were used as the data collection techniques. The data were then analyzed using the multiple regression analysis method. The results show that computer accounting learning achievement, teacher pedagogical competence, school environment and industrial work practices had a positive and significant effect on student work readiness with an effective contribution of $47.9 \%$. Many factors affect a person's work readiness. Work readiness can be influenced and shaped by the experience. Whereas environmental factors that can affect work readiness are the school environment, the pedagogical competence of the teachers and their success in industrial work practices.
\end{abstract}

Keywords: work readiness, academic achievement, pedagogical competence, industrial work practice 


\section{PENDAHULUAN}

Globalisasi secara umum dan dibentuknya Masyarakat Ekonomi ASEAN (MEA) pada akhir tahun 2015 tentu saja menjadi tantangan tersendiri bagi Indonesia, khususnya pada aspek sumber daya manusia dan lapangan pekerjaan. Jumlah penduduk yang banyak tetapi kurang diimbangi dengan kualitas merupakan beban bagi pembangunan nasional. Indonesia termasuk dalam ketegori tersebut. Hal ini dilihat dari peringkat daya saing Indonesia di dunia berdasarkan Growth Competitivines Index berada pada urutan 41 dari 138 negara, jauh tertinggal dari negara-ngerara di Asia Tenggara lainnya seperti Singapura yang ada di peringkat 2, Malaysia yang ada di peringkat 25 dan Thailand di peringkat 34 (Schwab, 2018). Indonesia perlu meningkatkan kualitas sumber daya manusia supaya dapat bersaing dengan negara lain, salah satunya dengan cara mengembangkan dan meningkatkan kualitas penyelenggaraan pendidikan di sekolah.

Sekolah merupakan tempat kegiatan belajar mengajar berlangsung. Slameto
(2013, p. 64) menyatakan bahwa faktor lingkungan sekolah yang mempengaruhi belajar meliputi metode mengajar, kurikulum, relasi guru dengan siswa, relasi siswa dengan siswa, disiplin sekolah, pelajaran dan waktu sekolah, standar pelajaran diatas ukuran, keadaan gedung, metode belajar dan tugas rumah. Oleh karena itu, sekolah menjadi suatu lingkungan yang khas sebagai lingkungan pendidikan, yaitu tempat berlangsungnya kegiatan belajar mengajar dengan segala sarana dan prasarana serta kondisi lingkungan yang mendukung berlangsungnya kegiatan belajar mengajar.

Dilihat dari tingkatan sekolah, Sekolah Menengah Atas (SMA) dipersiapkan untuk melanjutkan sekolah ke perguruan tinggi, sedangkan SMK lebih diorientasikan kepada lulusan yang siap bekerja. Tetapi hingga saat ini tujuan tersebut belum tercapai. Berdasarkan pendataan yang dilakukan oleh Badan Pusat Statistik (BPS) pada bulan Mei 2017 diketahui bahwa Tingkat Pengangguran Terbuka (TPT) di Indonesia berdasarkan jenjang pendidikan dapat dilihat pada Gambar 1.

Gambar 1. Grafik Tingkat Pengangguran Terbuka (TPT) Februari 2017

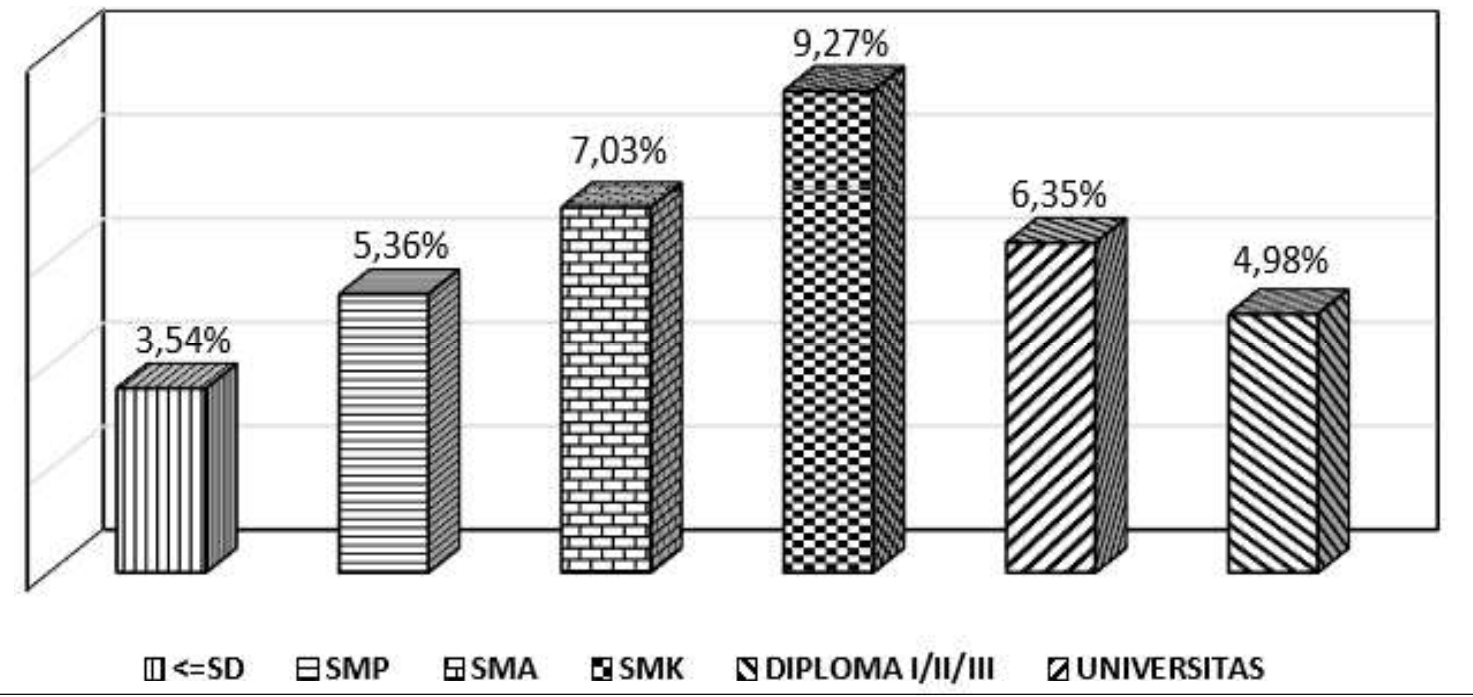


Gambar 1 menunjukkan bahwa untuk TPT untuk tingkat pendidikan SMK merupakan yang tertinggi diantara tingkat pendidikan lainnya, yaitu sebesar 9,27\%. Sedangkan TPT untuk tingkat pendidikan SD ke bawah merupakan yang terendah, yaitu sebesar 3,54\%. Data ini menunjukkan bahwa masih banyak lulusan SMK yang tidak terserap dalam dunia kerja. Pembelajaran di SMK baik di sekolah maupun dalam dunia kerja yang bertujuan mengarahkan dan membentuk siswa agar siap kerja belum terlaksana dengan baik.

Yogyakarta sebagai kota pendidikan juga masih menghadapi masalah dalam hal pengangguran. Menurut data Badan Pusat Statistik (BPS) Provinsi Daerah Istimewa Yogyakarta menyatakan pada tahun 2015 angka pencari kerja yang belum ditempatkan sebanyak 41.843 orang yang tersebar di 7 tingkat pendidikan dengan perincian SD sebanyak 145 orang, SMP sebanyak 853 orang, SMA sebanyak 3.440 orang, SMK sebanyak 7.046 orang, Diploma I-III sebanyak 7.530 orang dan Sarjana/ Diploma IV sebanyak 21.811 orang dan S2/ S3 sebanyak 1.018 orang. Angka tersebut menunjukkan tidak seimbangnya kebutuhan tenaga kerja dengan jumlah pencari kerja itu sendiri.

Hampf dan Woessmann (2017) menyebutkan bahwa individu yang menyelesaikan program pendidikan kejuruan pada awalnya memiliki kesempatan kerja yang lebih baik daripada individu yang menyelesaikan program pendidikan umum. Inovasi dalam pendidikan di SMK telah dilakukan oleh pemerintah untuk meningkatkan kesempatan kerja menjadi lebih baik lagi. Hal ini ditandai dengan jumlah SMK yang tumbuh pesat dimulai pada tahun 2010 dari sebesar 9.164 sekolah menjadi 11.708 sekolah pada tahun 2013 atau tumbuh sebesar 27,6\%. Jumlah SMK terbanyak adalah di Jawa Barat (2.125) diikuti dengan JawaTimur (1.654), Jawa Tengah (1.427), Sumatera Utara (901), dan DKI Jakarta (595). Sementara Provinsi dengan jumlah SMK terendah adalah Provinsi Papua Barat dengan 44 sekolah (Hadam, Rahayu, \& Ariyadi, 2017, p. 9).

Kesiapan kerja bagi siswa SMK sangat penting. Hal ini dikarenakan dalam waktu yang tidak lama, sebagian atau semua siswa akan menghadapi satu jenjang hidup yang lebih tinggi yaitu bekerja. Terdapat enam tujuan dari kesiapan (Slameto, 2010, p. 115), yaitu sebagai persiapan dalam mengambil keputusan, sarana mengembangkan rasa percaya diri, sarana menemukan makna diri, sarana ketenangan bagi diri untuk mengenal kesempatan baik, sarana mendapatkan ide atas yang seharusnya dikerjakan saat ini dan hubungannya dengan yang dapat dikerjakan seterusnya, dan sarana menolong yang harus disediakan pada setiap level baru dalam hidup. Hal ini sejalan dengan pendapat Jollands, Jolly, dan Molyneaux (2012) yang menyatakan bahwa kesiapan kerja adalah konsep yang bertujuan untuk menilai seberapa siap transisi dari lulusan ke dunia kerja. Ini dapat didefinisikan sebagai sebuah pelajaran yang memungkinkan lulusan untuk menerapkan pengetahuan teknis mereka yang dipelajari di sekolah untuk mengidentifikasi masalah dan penyelesaian masalah ketika berada dalam suatu pekerjaan. Dengan demikian, kesiapan kerja diperlukan untuk mencapai keberhasilan dalam suatu pekerjaan. Siswa SMK perlu memiliki kesiapan kerja untuk memasuki dunia kerja, baik itu kesiapan dari segi fisik, kesiapan mental, serta kesiapan dari proses pembelajaran di sekolah baik secara kognitif dan sebagainya. Ketika proses belajar dapat berjalan dengan baik, maka dapat dikatakan bahwa hal tersebut dapat memberikan dampak yang positif bagi perkembangan pencapaian tujuan. 
Slameto (2010, p. 113) menjelaskan bahwa faktor-faktor yang mempengaruhi kesiapan mencakup tiga aspek, yaitu kondisi fisik, mental dan emosional; kebutuhan-kebutuhan (motif dan tujuan); dan keteram-pilan (pengetahuan dan pengertian lain yang telah dipelajari). Untuk mengasah keterampilan akuntansi siswa, sekolah mengacu pada Permendikbud Nomor 70 Tahun 2013 tentang Kerangka Dasar dan Struktur Kurikulum SMK/MA Kejuruan memperkenalkan Mata Pelajaran Akuntansi Komputer sebagai kelompok kompetensi kejuruan.

Akuntansi komputer merupakan salah satu materi praktik akuntansi sebagai penyeimbang perkembangan teknologi saat ini yang diperkenalkan ketika siswa kelas XI. Hal ini sejalan dengan pernyataan Accounting Education Change Comission (Suryani, 2013) bahwa lulusan akuntansi harus mampu menempatkan, memperoleh, melaporkan, dan menggunakan informasi dari media elektronik. Marriot (Boulianne, 2014) juga berpendapat bahwa simulasi komputer dapat memberikan pengalaman kepada siswa sesuai dengan lingkungan kerja yang sebenarnya.

Pengukuran ketercapaian keberhasilan siswa dalam penguasaan program akuntansi komputer dari Praktik dan teori dapat dilihat prestasi belajar siswa. Bagi siswa kejuruan khususnya kompetensi keahlian akuntansi, prestasi belajar Mata Pelajaran Akuntansi Komputer yang tinggi menunjukkan bahwa siswa tersebut sudah menguasai materi akuntansi komputer dan dapat digunakan sebagai bekal pengetahuan untuk siap bekerja. Gaya belajar melalui aktivitas fisik dan keterlibatan langsung merupakan salah satu gaya belajar yang dimiliki siswa yang dapat mempengaruhi prestasi belajar siswa (Bire, Geradus, \& Bire, 2014). Prestasi belajar Mata Pelajaran Akuntansi Komputer siswa dapat dilihat dari bukti konkritnya yaitu berupa nilai Ulangan Akhir Semester (UAS).

Faktor guru sebagai subjek pelaksana pembelajaran sangat menentukan keberhasilan pendidikan itu sendiri, selain prestasi belajar. Dalam Undang-undang Republik Indonesia Nomor 14 Tahun 2005 tentang Guru dan Dosen disebutkan bahwa kompetensi guru meliputi kompetensi pedagogik, kompetensi kepribadian, kompetensi sosial, dan kompetensi profesional. Kompetensi utama yang harus dimiliki guru agar pembelajaran yang dilakukan efektif dan dinamis adalah kompetensi pedagogik (Asmani, 2009, p. 59). Sejalan dengan itu, Lestari dan Purwanti (2018) menyatakan bahwa kompetensi pedagogik merupakan salah satu kompetensi yang dapat menunjang seorang guru untuk mampu melaksanakan tugas keprofesionalannya dengan optimal sehingga membantu meningkatkan minat dan memotivasi siswa dalam pembelajaran agar mereka memperoleh keterampilan yang akan berguna untuk kesuksesan mereka di tempat kerja. Suciu dan Mata (2011) berpendapat bahwa penekanan dalam pemahaman kompetensi pedagogis yaitu dapat membantu siswa menguraikan kemampuan untuk memecahkan masalah dan tugas yang terjadi dalam situasi kegiatan di dunia kerja dengan menerapkan pengetahuan, pengalaman dan pengalaman hidup, nilai dan bakat dengan cara yang kreatif sehingga memperoleh hasil yang tepat dan efektif.

Suasana kondusif di sekolah juga diperlukan dalam menghasilkan pembelajaran yang efektif. Sekolah adalah suatu tempat yang di dalamnya terjadi hubungan saling ketergantungan antara manusia dengan lingkungannya. Lingkungan sekolah dapat membentuk kepribadian siswa melalui pembelajaran dan peraturanperaturan yang ada disekolah, lingkungan sekolah juga memberikan pengajaran yang 
belum didapatkan dari lingkungan keluarga. Pendidikan yang berwawasan lingkungan berupaya menerapkan prinsip-prinsip dan metodologi ke arah pembentukan kecakapan hidup (lifeskill) pada peserta didik melalui kurikulum terintegrasi yang dikembangkan di sekolah (Suyitno, Kamal, Sunoto, \& Suherjanto, 2016). Pembelajaran dengan memanfaatkan lingkungan lebih bersifat kontekstual dan lebih bermanfaat bagi kehidupan siswa di masyarakat.

Pada proses pembelajaran di SMK, peserta didik mengikuti program Praktik Kerja Industri yang merupakan bagian kurikulum SMK. Praktik kerja industri akan menggambarkan keterlibatan siswa dalam suatu pekerjaan yang nyata sesuai dengan bidang keahliannya, selain itu siswa akan memperoleh pengalaman untuk memperluas pengetahuannya tentang dunia kerja. Oluwale, Jegede, dan Olamade (2013) menyatakan bahwa pendidikan kejuruan adalah kegiatan terorganisir yang dirancang untuk menghasilkan pembelajaran sebagai persiapan untuk pekerjaan di bidang perdagangan atau pekerjaan yang sesuai di bidang keahliannya, tidak teoritis dan terfokus pada pencapaian kemampuan dalam keterampilan. Gambar 2 menyajikan hubungan antarvariabel dalam penelitian ini.

Berdasarkan Gambar 2, penelitian ini bertujuan untuk mengetahui bagaimana pengaruh secara individual dan simultan prestasi belajar akuntansi komputer, kompetensi pedagogik guru, lingkungan sekolah dan Praktik kerja industri terhadap kesiapan kerja siswa Program Keahlian Akuntansi SMK di Daerah Istimewa Yogyakarta.

\section{METODE}

Penelitian ini merupakan penelitian asosiatif kausal dengan sasaran siswa kelas XII Program Keahlian Akuntansi SMK Daerah Istimewa Yogyakarta tahun pelajaran 2018/2019. Populasi dalam penelitian ini sebanyak 429 siswa terdiri atas lima sekolah yang dipilih secara random mewakili lima wilayah di Daerah Istimewa Yogyakarta dan kemudian ditentukan jum-

Gambar 2. Hubungan Antarvariabel

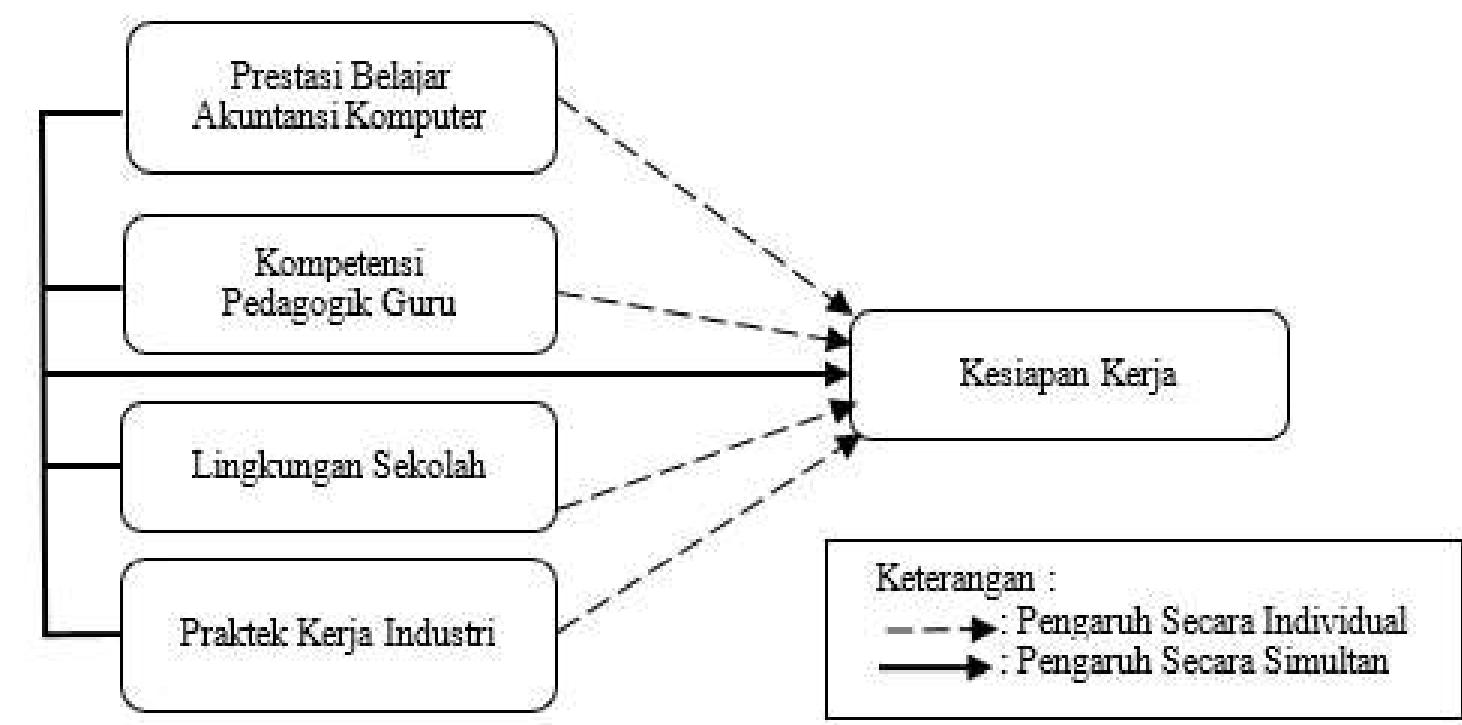


lah sampel siswa yang berada di masingmasing SMK secara proportionate random sampling dengan rincian yang disajikan pada Tabel 1.

Teknik pengumpulan data menggunakan kuesioner dan dokumentasi. Penyebaran kuesioner dilakukan dengan datang langsung ke sekolah dan memberikan kuesioner kepada siswa. Data kemudian dianalisis dengan metode analisis regresi berganda. Seluruh variabel penelitian diukur dengan menggunakan skala likert $1-4$ poin mulai dari tidak setuju/tidak pernah (skala 1) sampai dengan sangat setuju/selalu (skala 5). Instrumen penelitian divalidasi oleh para ahli dan diujicobakan untuk memastikan validitas dan reliabilitasnya.

Data yang diperoleh dianalisis secara deskriptif dan inferensial. Analisis deskriptif dilakukan dengan mendeskripsikan data yang telah diperoleh berdasarkan nilai maksimum, minimum, ratarata (mean), dan standar deviasi. Uji normalitas, uji multikolinearitas, uji heteroskedastisitas, dan uji autokorelasi dilakukan sebelum analisis inferensial dengan regresi berganda dikerjakan. Analisis regresi berganda dilakukan untuk menguji pengaruh prestasi belajar siswa, kompetensi pedagogik guru, lingkungan sekolah dan praktik kerja industri secara bersama-sama (simultan) terhadap kesiapan kerja siswa.

\section{HASIL PENELITIAN DAN PEMBAHASAN}

Penelitian ini menggunakan data sebanyak 207 orang siswa kelas XII Program Keahlian Akuntansi SMK Daerah Istimewa Yogyakarta Tahun Pelajaran 2018/2019. Karakteristik responden yang diperoleh terdiri atas jenis kelamin, pekerjaan orang tua, pendidikan terakhir orang tua, dan keputusan setelah lulus disajikan pada Tabel 2.

Tabel 2 menunjukkan bahwa responden penelitian didominasi oleh siswa perempuan yaitu sebanyak 186 orang $(89,9 \%)$ sedangkan siswa lakilaki merupakan populasi terkecil hanya sebanyak 21 orang $(10,1 \%)$. Berdasarkan pekerjaan orang tua siswa, terbanyak adalah sebagai buruh yaitu sebanyak 165 orang $(79,7 \%)$ kemudian diikuti dengan pekerjaan orang tua siswa sebagai wiraswasta sebanyak 37 orang (17,9\%) dan yang paling sedikit pekerjaan orang tua siswa sebagai PNS hanya sebanyak 5 orang $(2,4 \%)$. Berdasarkan pendidikan terakhir orang tua siswa, terbanyak pada jenjang SD yaitu sebanyak 68 orang (32,9\%) kemudian diikuti pada jenjang SMA sebanyak 67 orang $(32,4 \%)$ dan yang paling kecil terdapat pada jenjang SMK yang hanya 6 orang $(2,9 \%)$. Berdasarkan keputusan setelah lulus, sebanyak 40 siswa $(19,3 \%)$ berkeinginan untuk bekerja setelah lulus nantinya sedangkan 167 siswa

Tabel 1

Sampel Penelitian

\begin{tabular}{lrc}
\hline \multicolumn{1}{c}{ Sekolah } & Populasi & Sampel \\
\hline SMK Muhammadiyah 1 Yogyakarta & 60 siswa & 29 siswa \\
SMK Negeri 1 Bantul & 128 siswa & 62 siswa \\
SMK Yapemda Sleman & 52 siswa & 25 siswa \\
SMK Negeri 1 Wonosari & 125 siswa & 60 siswa \\
SMK Negeri 1 Pengasih & 64 siswa & 31 siswa \\
\hline \multicolumn{1}{c}{ Jumlah } & 429 siswa & 207 siswa \\
\hline
\end{tabular}


Tabel 2

Karakteristik Responden

\begin{tabular}{lcc}
\hline Karakteristik & F & $\%$ \\
\hline Jenis Kelamin: & & \\
1. Laki-laki & 21 & 10,1 \\
2. Perempuan & 186 & 89,9 \\
Pekerjaan Orang Tua: & & \\
1. Buruh & 165 & 79,7 \\
2. Wiraswasta & 37 & 17,9 \\
3. PNS & 5 & 2,4 \\
Pendidikan Terakhir Orang Tua: & & \\
1. SD & 68 & 32,9 \\
2. SMP & 54 & 26,1 \\
3. SMA & 67 & 32,4 \\
4. SMK & 6 & 2,9 \\
5. Sarjana & 12 & 5,8 \\
Keputusan Setelah Lulus: & & \\
1. Melanjutkan Studi & 167 & 80,7 \\
2. Bekerja & 40 & 19,3 \\
\hline
\end{tabular}

(80,7\%) menyatakan keinginannya untuk melajutkan studi ke jenjang yang lebih tinggi lagi.

Variabel penelitian dideskripsikan pada Tabel 3. Tabel 3 menunjukkan bahwa prestasi belajar siswa sebanyak 191 siswa $(92,3 \%)$ berada pada kategori tuntas dan sisanya sebanyak 16 siswa $(7,7 \%)$ berada dalam kategori belum tuntas. Untuk kompetensi pedagogik guru, siswa memberikan penilaian terhadap kompetensi pedagogik guru dalam kategori sedang sebanyak 124 siswa $(59,9 \%)$, kategori rendah sebanyak 83 siswa $(40,1 \%)$. Artinya, mayoritas menurut siswa, kompetensi pedagogik guru dalam kategori sedang. Untuk lingkungan sekolah, siswa yang memberikan penilaian terhadap lingkungan sekolah dalam kategori sedang sebanyak 178 siswa (86\%) dan kategori rendah sebanyak 29 siswa (14\%). Artinya, mayoritas menurut siswa, lingkungan sekolah dalam kategori sedang. Untuk praktik kerja industri, diketahui nilai praktik kerja industri siswa pada kategori tuntas sebanyak 116 siswa $(56,1 \%)$ dan kategori yang belum tuntas sebanyak 91 siswa $(43,9 \%)$. Kesiapan kerja siswa masuk dalam kategori sedang sebanyak 205 siswa (99\%) dan kategori rendah sebanyak 2 siswa (1\%). Artinya, mayoritas kesiapan kerja siswa dalam kategori sedang.

Sebelum analisis regresi berganda dilakukan, terlebih dahulu dilakukan uji asumsi klasik, yaitu uji normalitas, uji multikolinearitas, uji heteroskedastisitas, dan uji autokorelasi. Hasil uji asumsi klasik tersebut dapat dilihat pada Tabel 4. Tabel 4 menunjukkan bahwa nilai Asymp. Sig (2-tailed) sebesar 0,147 lebih besar dari 0,05 sehingga dapat disimpulkan bahwa data berdistribusi normal. Pada uji 
Tabel 3

Deskriptif Variabel Penelitian

\begin{tabular}{lccc}
\hline \multicolumn{1}{c}{ Kategori } & Interval Skor & $\mathrm{F}$ & $\%$ \\
\hline Prestasi Belajar Siswa & & & \\
$\quad$ Tuntas & & 191 & 92,3 \\
Belum Tuntas & $<78$ & 16 & 7,7 \\
Kompetensi Pedagogik Guru & $\mathrm{X} \geq 79,00$ & 0 & 0 \\
$\quad$ Tinggi & $64,89 \leq \mathrm{X}<79,00$ & 124 & 59,9 \\
Sedang & $\mathrm{X}<64,89$ & 83 & 40,1 \\
Rendah & & & \\
Lingkungan Sekolah & $\mathrm{X} \geq 80,27$ & 0 & 0 \\
Tinggi & $65,08 \leq \mathrm{X}<80,27$ & 178 & 86 \\
Sedang & $\mathrm{X}<65,08$ & 29 & 14 \\
Rendah & & & \\
Praktik Kerja Industri & $\geq 78$ & 116 & 56,1 \\
Tuntas & $<78$ & 91 & 43,9 \\
Belum Tuntas & $\mathrm{X}$ & & \\
Kesiapan Kerja Siswa & $65,43 \leq \mathrm{X}<79,46$ & 0 & 0 \\
Tinggi & $\mathrm{X}<65,43$ & 205 & 99 \\
Sedang & & & 1 \\
Rendah & &
\end{tabular}

Tabel 4

Uji Asumsi Klasik

\begin{tabular}{lccccc}
\hline \multicolumn{1}{c}{ Variabel } & \multicolumn{5}{c}{ Uji } \\
\hline & $\begin{array}{c}\text { Normalitas } \\
\text { Asymp. Sig. } \\
\text { (2-tailed) }\end{array}$ & $\begin{array}{l}\text { Multikolinearitas } \\
\text { Tolerance }\end{array}$ & VIF & Heteroskedastisitas & $\begin{array}{c}\text { Autokorelasi } \\
\text { Durbin } \\
\text { Watson }\end{array}$ \\
\hline Prestasi Belajar & 0,147 & 0,905 & 1,106 & 0,081 & 1,803 \\
Kompetensi Pedagogik & & 0,917 & 1,090 & 0,753 & \\
Lingkungan Sekolah & & 0,906 & 1,103 & 0,126 & \\
Praktik Kerja Industri & & 0,980 & 1,020 & 0,911 & \\
\hline
\end{tabular}

multikolinearitas, diketahui bahwa nilai tolerance yang diperoleh tiap variabel independent lebih kecil dari 0,1 dan nilai VIF lebih kecil dari 10, yang berarti tiap variabel independent dalam penelitian ini tidak terjadi multikolinearitas. Pada uji heteroskedastisitas, terlihat bahwa nilai signifikansi dari semua variabel independen lebih besar dari 0,05 sehingga dapat disimpulkan bahwa model regresi pada penelitian ini tidak terjadi heteroskedastisitas. Pada uji autokorelasi, menunjukkan nilai Durbin Watson sebesar 1,803 . Selanjutnya, dilakukan pengambilan 
keputusan dengan ketentuan $\mathrm{du}<\mathrm{d}<4$-du $(1,183<1,803<4-2,817)$. Hasil pengambilan keputusan menunjukkan bahwa tidak terdapat autokorelasi positif maupun negatif antar variabel sehingga model regresi layak digunakan. Hasil analisis regresi linear berganda dalam penelitian ini dapat dilihat pada Tabel 5. Berdasarkan hasil uji regresi linear berganda tersebut diperoleh persamaan regresi sebagai berikut.

$\mathrm{Y}=14,670+0,315$ Prestasi Belajar +

0,302 Kompetensi Pedagogik + 0,734

Lingkungan Sekolah + 0,154 Praktik

Kerja Industri

Tabel 5 menunjukkan bahwa nilai $\mathrm{t}_{\text {hitung }}$ untuk prestasi belajar sebesar 6,429 $(\mathrm{p}=0,000)$ menunjukkan bahwa prestasi belajar siswa berpengaruh positif dan signifikan terhadap kesiapan kerja. Hasil penelitian tersebut didukung oleh penelitian Widyatmoko (2014) yang mengatakan bahwa prestasi belajar berpengaruh positif dan signifikan terhadap kesiapan kerja mahasiswa Jurusan Pendidikan Ekonomi. Penelitian Valid dan Taman (2012) juga menemukan bahwa terdapat pengaruh positif dan signifikan prestasi belajar terhadap kesiapan kerja siswa.

Nilai $t_{\text {hitung }}$ untuk kompetensi pedagogik guru sebesar 2,892 ( $p=0,004)$.
Hal ini menunjukkan bahwa kompetensi pedagogik guru berpengaruh positif dan signifikan terhadap kesiapan kerja. Temuan penelitian ini juga didukung oleh pendapat Trilling dan Fadel (2009) yang menyatakan bahwa dalam mengajar siswa, guru perlu meningkatkan kompetensi pedagogik, menggunakan teknologi yang kuat yang tersedia saat ini untuk mendidik anak-anak dan membantu mereka menjadi pemikir kritis dan pemecah masalah sehingga mereka memperoleh keterampilan yang akan menjadi mesin untuk kesuksesan mereka di tempat kerja, perdagangan, pekerjaan, dan profesi abad ke-21 sehingga memenuhi tujuan moral pendidikan.

Nilai $t_{\text {hitung }}$ untuk lingkungan sekolah sebesar $8,301(\mathrm{p}=0,000)$. Hal ini menunjukkan bahwa lingkungan sekolah berpengaruh positif dan signifikan terhadap kesiapan kerja. Sekolah harus meningkatkan kesadaran karir dan rencana belajar individual untuk setiap siswa (Evans, Davis, \& Wheeler, 2017, p. 89). Rencana belajar individual dapat meningkatkan keberhasilan pilihan kursus, membantu memaksimalkan pengalaman di sekolah. dan mengembangkan keterampilan terapan yang dibutuhkan untuk sukses di tempat kerja. Hasil penelitian ini didukung

Tabel 5

Hasil Uji Regresi Linear Berganda

\begin{tabular}{lccc}
\hline \multicolumn{1}{c}{ Model } & Beta & $t$ & Sig \\
\hline \multicolumn{1}{c}{ (Constant) } & 14,670 & 1,617 & 0,107 \\
Prestasi Belajar & 0,315 & 6,429 & 0,000 \\
Kompetensi Pedagogik & 0,302 & 2,892 & 0,004 \\
Lingkungan Sekolah & 0,734 & 8,301 & 0,000 \\
Praktik Kerja Industri & 0,154 & 2,484 & 0,014 \\
\hline
\end{tabular}

F Hitung $=48,372$

Signifikansi $=0,000$

Adjusted $R^{2}=0,479$ 
juga dengan penelitian Alfan (2014) yang menyatakan bahwa terdapat pengaruh antara lingkungan sekolah terhadap kesiapan kerja siswa.

Nilai $\mathrm{t}_{\text {hitung }}$ untuk praktik kerja industri sebesar 2,484 ( $p=0,014)$. Hal ini menunjukkan bahwa praktik kerja industri berpengaruh positif dan signifikan terhadap kesiapan kerja. Hasil penelitian ini sejalan dengan temuan penelitian Triwahyuni dan Setiyani (2016) yaitu ada pengaruh positif praktik kerja industri terhadap kesiapan kerja siswa SMK. Sejalan dengan pendapat (Chen \& Shen, 2012) yang menyatakan bahwa perencanaan program magang dan keterlibatan industri memiliki pengaruh paling besar terhadap keinginan siswa untuk tetap di industri setelah lulus.

Penelitian ini juga menyimpulkan bahwa prestasi belajar siswa, kompetensi pedagogik guru, lingkungan sekolah, dan praktik kerja industri secara simultan berpengaruh terhadap kesiapan kerja $\left(\mathrm{F}_{\text {hitung }}=48,372 ; \mathrm{p}=0,000\right)$. Tabel 5 menunjukkan bahwa nilai Adjusted $R$ Square sebesar 0,479. Hal ini berarti besar pengaruh prestasi belajar siswa, kompetensi pedagogik guru, lingkungan sekolah, dan praktik kerja industri terhadap kesiapan kerja sebesar $47,9 \%$. Sedangkan sisanya sebesar 52,1\% dipengaruhi oleh variabel lain yang tidak diteliti dalam penelitian ini. Temuan penelitian ini diperkuat dengan pernyataan yang dikemukakan oleh Conley
(2013, p. 96) yang menyatakan bahwa keahlian yang diperlukan untuk kesiapan karier/kerja mencakup strategi kognitif seperti komunikasi, struktur pengetahuan, keterampilan, teknik pembelajaran yang memungkinkan peserta didik untuk menyadari cara mereka belajar dan mampu mengambil manfaat dari yang mereka pelajari.

Tabel 6 menyajikan sumbangan relatif dan sumbangan efektif variabel prestasi belajar, kompetensi pedagogik, lingkungan sekolah, dan praktik kerja industri. Tabel 6 menunjukkan bahwa prestasi belajar siswa memiliki sumbangan relatif sebesar 34,4\% dan sumbangan efektif sebesar 16,8\%. Variabel kompetensi pedagogik guru memiliki sumbangan relatif sebesar $10,2 \%$ dan sumbangan efektif sebesar 5,1\%. Variabel lingkungan sekolah memiliki sumbangan relatif sebesar $50,6 \%$ dan sumbangan efektif sebesar $24,7 \%$ serta variabel praktik kerja industri memiliki sumbangan relatif sebesar $4,8 \%$ dan sumbangan efektif sebesar 2,3\%. Hasil tersebut menunjukkan bahwa keempat variabel bebas memberi pengaruh terhadap variabel terikat sebesar $47,9 \%$ dan sebesar $52,1 \%$ dipengaruhi oleh faktor lain yang tidak diteliti dalam penelitian ini.

\section{SIMPULAN}

Berdasarkan hasil pengujian dan pembahasan dapat disimpulkan bahwa prestasi

Tabel 6

Sumbangan Relatif dan Sumbangan Efektif

\begin{tabular}{lcc}
\hline \multicolumn{1}{c}{ Variabel } & Sumbangan Relatif (\%) & Sumbangan Efektif (\%) \\
\hline Prestasi Belajar & 34,4 & 16,8 \\
Kompetensi Pedagogik & 10,2 & 5,1 \\
Lingkungan Sekolah & 50,6 & 24,7 \\
Praktik Kerja Industri & 4,8 & 2,3 \\
\hline \multicolumn{1}{c}{ Jumlah } & 100 & 47,9 \\
\hline
\end{tabular}


belajar siswa, kompetensi pedagogik guru, lingkungan sekolah, dan Praktik kerja industri berpengaruh baik secara simultan dan parsial terhadap kesiapan kerja. Besarnya sumbangan efektif prestasi belajar siswa, kompetensi pedagogik guru, lingkungan sekolah, dan praktik kerja industri secara simultan terhadap kesiapan kerja siswa adalah 47,9\%. Banyak faktor-faktor yang mempengaruhi kesiapan kerja seseorang siswa. Kesiapan kerja dapat dipengaruhi dan dibentuk oleh pengalaman. Pengalaman tersebut dapat diperoleh melalui pendidikan dan lingkungan sekitarnya. Secara implisit kesiapan kerja ini dapat diusahakan melalui diri siswa itu sendiri yang terwujud dalam prestasi belajarnya. Sedangkan faktor lingkungan yang dapat mempengaruhi kesiapan kerja yaitu lingkungan sekolah, kompetensi pedagogik guru yang mengajar dan keberhasilan mereka dalam praktik kerja industri.

Saran yang dapat diberikan bagi siswa hendaknya berdiskusi dengan teman sekelasnya untuk mencari solusi atas hambatan dalam pemahaman materi pelajaran akuntansi komputer atau bertanya langsung kepada Bapak/Ibu guru mengenai Materi Pelajaran Akuntansi Komputer yang belum dipahami serta mengerjakan soal-soal latihan yang terdapat pada buku paket untuk mengukur seberapa besar tingkat pemahaman peserta didik terhadap materi yang telah disampaikan guru tersebut supaya dapat meningkatkan prestasi belajar akuntansi komputer siswa yang akan berdampak pada peningkatan kesiapan kerja siswa. Untuk guru sebaiknya harus aktif dalam mencari berbagai informasi yang relevan untuk meningkatkan kompetensi pedagogik yang dimiliki, selain itu guru perlu membangkitkan kesadarannya atas tanggung jawabnya sebagai guru untuk berpartisipasi di berbagai pelatihan, forum maupun pendidikan demi meningkatkan pengetahuan dan wawasan yang sesuai dengan tuntutan jaman. Sementara bagi peneliti selanjutnya diharapkan dapat meneliti faktor-faktor lain yang juga mempengaruhi kesiapan kerja siswa, sehingga dapat diketahui kontribusi yang diberikan untuk kesiapan kerja.

\section{DAFTAR PUSTAKA}

Alfan, M. Z. (2014). Pengaruh bimbingan karir dan lingkungan sekolah melalui motivasi kerja terhadap kesiapan kerja siswa kelas XII Kompetensi Keahlian Akuntansi SMK Negeri 2 Magelang. Economic Education Analysis Journal, 3(1), 114-123.

Asmani, J. M. (2009). 7 kompetensi guru menyenangkan dan profesional. Yogyakarta: Power Books.

Badan Pusat Statistik Provinsi D.I. Yogyakarta. (2015). Angka pencari kerja yang belum ditempatkan tahun 2015. Dunduh dari http://yogyakarta. bps.go.id// pada tanggal 4 April 2018.

Badan Pusat Statistik. (2016). Tingkat pengangguran. Diunduh dari http:// www.bps.go.id// pada tanggal $15 \mathrm{Mei}$ 2017.

Bire, A. L., Geradus, U., \& Bire, J. (2014). Pengaruh gaya belajar visual, auditorial, dan kinestetik terhadap prestasi belajar siswa. Jurnal Kependidikan, 44(2), 168-174.

Boulianne, E. (2014). Impact of accounting software utilization on students knowledge acquisition: An important change in accounting education. Jurnal of Accounting and Organizational Change, 10(1), 22-48.

Chen, T., \& Shen, C. (2012). Leisure, sport \& tourism education today's intern, tomorrow's practitioner? - The influence of internship programmes on students' career development 
in the hospitality industry. Journal of Hospitality, Leisure, Sport \& Tourism Education, 11(1), 29-40. doi. org/10.1016/j.jhlste.2012.02.008.

Conley, D. T. (2013). Getting ready for college, careers, and the common core: What every educator needs to know. Malden, MA: John Wiley \& Sons

Evans, S. G., Davis, J., \& Wheeler, M. (2017). An analysis of school-to-work readiness (Doctoral dissertation). Saint Louis University, Saint Louis.

Hadam, S. Rahayu, N., \& Ariyadi, A, N. Strategi implementasi revitalisasi SMK (10 langkah revitalisasi SMK). Jakarta: Direktorat Pembinaan Sekolah Menengah Kejuruan, Ditjen Pendidikan Dasar dan Menengah, Kementerian Pendidikan dan Kebudayaan.

Hampf, F., \& Woessmann, L. (2017). Vocational vs. general education and employment over the life cycle: New evidence from PIAAC. CESifo Economic Studies, 63(3), 255-269.

Jollands, M., Jolly, L., \& Molyneaux, T. (2012). Project-based learning as a contributing factor to graduates' work readiness, European Journal of Engineering Education, 37(2), 143154.

Lestari, Y. A., \& Purwanti, M. (2018). Hubungan kompetensi pedagogik, profesional, sosial, dan kepribadian pada guru sekolah nonformal X. Jurnal Kependidikan, 2(1), 197-208.

Menteri Pendidikan dan Kebudayaan (2013). Permendikbud Nomor 70 Tahun 2013 tentang Kerangka Dasar dan Struktur Kurikulum SMK-MAK. Jakarta: Kemdikbud.

Oluwale, B. A., Jegede, O. O., \& Olamade, O. O. (2013). Technical and vocational skills depletion in Nigeria and the need for policy intervention. International
Journal of Vocational and Technical Education, 5(6), 100-109.

Presiden Republik Indonesia. (2005). Undang-undang RI Nomor 14 Tahun 2005 tentang Sistem Pendidikan Nasional. Jakarta.

Schwab, K. (2018, December). The global competitiveness report 2018. Dalam World Economic Forum (pp. 9-14). Geneva.

Slameto. (2010). Belajar dan faktor-faktor yang mempengaruhi. Jakarta: Rineka Cipta.

Slameto. (2013). Belajar dan faktor-faktor yang mempengaruhi. Jakarta: Rineka Cipta.

Suciu, A. I., \& Mata, L. (2011). Pedagogical competences-the key to efficient education. International Online Journal of Educational Sciences, 3(2), 411-423.

Suryani, I. (2013). Pengaruh penggunaan informasi akuntansi manajemen dan desentralisasi terhadap kinerja manajerial (Survei pada Dealer Mobil Kota Jambi). e-Jurnal Binar Akuntansi, 2(1).

Suyitno, I., Kamal, M., Sunoto, \& Suherjanto, I. (2016). Teknik pembelajaran observasi lingkungan berbasis kearifan lokal. Jurnal Kependidikan, 46(1). 14-28.

Trilling, B. \& Fadel, C. (2009). $21^{\text {st }}$ century skills: Learning for life in our times. San Francisco, CA: Jossey-Bass.

Triwahyuni, H., \& Setiyani, R. (2016). Pengaruh prakerin, prestasi akademik mata diklat produktif akuntansi, dan pemanfataan bank mini terhadap kesiapan kerja siswa SMK Kompetensi Keahlian Akuntansi. Economic Education Analysis Journal, 5(1), 58-71

Walker, A., Yong, M., Pang, L., Fullarton, C., Costa, B., \& Dunning, A. M. T. (2013). Nurse education today 
work readiness of graduate health professionals. YNEDT, 33(2), 116-122. doi.org/10.1016/j.nedt.2012.01.007.

Widyatmoko, Y.(2014). Pengaruh keaktifan mahasiswa dalam organisasi dan prestasi belajar terhadap kesiapan kerja mahasiswa Jurusan Pendidikan Ekonomi Universitas Negeri Yogyakarta (Skripsi tidak diterbitkan).
Universitas Negeri Yogyakarta, Yogyakarta.

Valid, Y. M., \& Taman, A. (2013). Pengaruh pengalaman praktik industri dan prestasi belajar terhadap kesiapan kerja siswa kelas XI Program Keahlian Akuntansi SMK YPKK 2 Sleman Yogyakarta. Kajian Pendidikan Akuntansi Indonesia, 2(1), 161-183. 